\title{
Uvádění začínajících učitelů v mateřských, základních a středních školách pohledem jeho hlavních aktérů
}

\author{
Klára Záleskáa, Libor Juhaňák ${ }^{\mathrm{b}}$, Kateřina Trnkovác, \\ Martina Šmahelová d \\ ${ }^{\mathrm{a}, \mathrm{b}}$ Masarykova univerzita, Filozofická fakulta, Ústav pedagogických věd \\ ${ }^{c}$ Národní institut pro další vzdělávání \\ ${ }^{\mathrm{d}}$ Masarykova univerzita, Fakulta sociálních studií, Institut výzkumu dětí, mládeže a rodiny
}

Redakci zasláno 10.1. 2019 / upravená verze obdržena 22. 5. 2019 /

/ k uveřejnění přijato 22. 5. 2019

\begin{abstract}
Abstrakt: Adaptace začínajících učitelů na školách není izolovaným procesem. Významně do ní vstupují kolegové (především uvádějící učitelé) a vedení školy. 0 jejich působení při uvádění začínajících učitelů však zatím nevíme mnoho. Cílem předkládané studie je proto popsat současnou podobu uvádění začínajících učitelů do praxe českých škol a zmapovat potřeby jednotlivých aktérů vstupujících do tohoto procesu. $\mathrm{K}$ tomu bylo použito kvantitativně orientované šetření, v němž byly dotazníkem osloveny tři skupiny respondentů: začínající učitelé, uvádějící učitelé a osoby odpovědné za uvádění začínajících učitelů, a to v mateřských, základních a středních školách. Vybrané výsledky prezentují typické znaky současného stavu uvádění začínajících učitelů, základní potřeby sledovaných skupin respondentů v tomto procesu a vnímanou profesní perspektivu respondentů.
\end{abstract}

Klíčová slova: začínající učitel, uvádějící učitel, osoba odpovědná za proces uvádění, podpora začínajících učitelů, adaptační plán, další vzdělávání pedagogických pracovníků

První roky učitelské praxe bývají často označovány za vůbec nejtěžší v učitelské kariéře (Švaříček, 2007; Eldar, 2003; Šimoník, 1994). Začínající učitelé1 se totiž nachází v citlivém období, kdy přestávají být studenty a adaptují se na roli učitelů. Řada z nich v této etapě zažívá tzv. „šok z praxe“ (Johnson \& Kardos, 2005; Stokking et al., 2003). Loevingerová (1976) dokonce hovoří o fázi „obav o přežití“ (survival concerns phase). Začínající učitelé čelí

1 Podle Průchy, Walterové a Mareše (2009, s. 377) je začínající učitel mladý a nezkušený učitel, který má dokončené pedagogické vzdělání a pedagogickou způsobilost, ale chybí mu právě pedagogická zkušenost. Jelikož od prvních dnů učitelské kariéry vykonává své povinnosti v plné širri, potřebuje systematickou podporu. 
v prvních letech své praxe řadě výzev. Často například nemají přístup k jasným odpovědím týkajícím se chodu školy ani k ukázkám dobré praxe, čímž je značně ohrožena kvalita výuky začínajících učitelů. Ti pak často zpochybňují svou profesní kompetenci, což může vést až k celkovému zpochybňování výběru učitelství jako své profese. Řada začínajících učitelů ve škole zažívá pocit nedostatečné kolegiality, mají nedostatek času na plnění svých povinností, čelí nedostatečné zpětné vazbě na svou práci, chybí jim ocenění jejich snahy, prožívají nereálná očekávání ve vztahu ke svému působení ve škole a také obtíže při hledání správné rovnováhy mezi osobním životem a prací (Sorcinelli, 1992, s. 33).

Z těchto důvodů se řada začínajících učitelů rozhodne opustit školství a hledají si práci mimo vzdělávací sektor. Drop-out mezi začínajícími učiteli je podle zprávy OECD $\left(2005\right.$, s. 11) v některých státech až $10 \%{ }^{2}$ To vede jednak k neúčinnému využívání zdrojů investovaných do systému vzdělávání budoucích učitelů, jednak ke snížení počtu mladých učitelů ve školách. Udržení začínajících učitelů ve školství však lze považovat za zásadní. Pro školy mohou být zdrojem inovativních a inspirujících nápadů, dokonce jistými agenty změny. Výzkumy však ukazují, že začínající učitelé bývají spíše rychle zahrnuti do již existujících struktur školy a prostoru pro realizaci svých nápadů dostávají málo. To může být další z podstatných důvodů drop-outu začínajících učitelů (EU Commission, 2010, s. 15; Píšová \& Hanušová, 2016, s. 397).

Obava z nedostatku mladých učitelů je důvodem, proč téma podpory uvádění začínajících učitelů do praxe považujeme za důležité nejen pro každodenní fungování škol, ale i pro vzdělávací politiku. Nedostatek začínajících učitelů spolu se stárnutím učitelských sborů totiž může do značné míry narušit kontinuitu v pojetí českého kurikula a vzdělanosti (Dvořák et al., 2011). Z těchto pohnutek je pro tvůrce vzdělávacích politik jednotlivých států důležité vyvíjet opatření, která podpoří profesionální rozvoj učitelů, a to od kvalitního pregraduálního vzdělávání budoucích učitelů až po odchod učitele do důchodu (Breaux \& Wong, 2003).

Na evropské úrovni je podpora uvádění začínajících učitelů diskutovaným tématem již řadu let. $V$ roce 2009 se naprríklad evropští ministři školství v Gothenburgu shodli, že je nutné usilovat o to, aby všichni začínající učitelé dostali během prvních let své kariéry dostatečnou a účinnou podporu (EU Commission, 2010, s. 5). Tento společný imperativ nabírá v jednotlivých

2 Detailněji o drop-outu začínajících učitelů viz literární přehled Píšové a Hanušové (2016). 
evropských zemích různých podob. Obecně lze říci, že podoba podpory začínajících učitelů bývá bud' formální (začínající učitelé mají povinnost projít některým z tzv. indukčních programů), nebo neformální (kdy je účast na podpůrných aktivitách dobrovolná) (EU Commission, 2010, s. 34). V posledních letech je na evropské půdě věnována velká pozornost kvalitě přípravy budoucích učitelů již na pedagogických fakultách a dalšímu vzdělávání pedagogických pracovníků. Zdaleka ne tolik pozornosti bylo doposud věnováno tvorbě efektivních podpůrných programů, které pomáhají učitelům překonat fázi začínajícího učitele a přejít do fáze zkušeného učitele. Navíc ojedinělá opatření některých evropských států zůstávají spíše nesystematická a nedopracovaná, než že by byla ve vzdělávacích systémech dobře zakotvena ${ }^{3}$ (EU Commission, 2010, s. 7; ETUCE, 2008, s. 48).

Indukční fáze, během které by měli začínající učitelé dostávat systematickou podporu, by měla trvat minimálně jeden rok a pro začínající učitele by měla

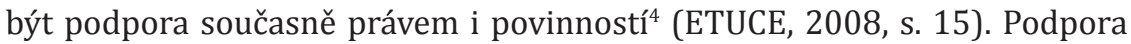
má podle dokumentu zahrnovat: (a) podporu od mentorů, resp. uvádějících učitelů a ostatních kolegů, (b) snížení počtu hodin výuky bez snížení odměny, (c) snadný přístup k podpůrným zdrojům, (d) povinnou účast na poradenských programech či (e) příležitosti, jak systematicky přenášet teoretické poznatky o výuce do své učitelské praxe (EU Commission, 2010, s. 4).

Stejně jako ve většině evropských států ani v České republice (dále jen v ČR) není v současnosti podpora začínajících učitelů ošetřena systémově ani legislativně. I když tak tomu nebylo vždy. Na nutnost podpory začínajících učitelů reagovala již vyhláška ministerstva školství České socialistické republiky č. 79 a vyhláška ministerstva školství Slovenské socialistické republiky č. 80 (obě z roku 1977), které zabezpečovaly všem začínajícím učitelům přidělení uvádějícího učitele. Po roce 1985 se od této povinnosti ustoupilo. Přibližně od počátku nového tisíciletí se opět objevují snahy o legislativní ukotvení podpory začínajících učitelů v jejich uvádění do praxe (Rýdl, 2009). Současná legislativa (zákon 563/2004 Sb., o pedagogických pracovnících a o změně některých zákonů, hlava IV) sice popisuje další vzdělávání a kariérní systém

\footnotetext{
Více o zahraničním kontextu adaptačního období začínajících učitelů na příkladu zkušeností z vybraných zemí viz Janík et al (2017).

4 Dále o důležitosti indukce v učitelské podpoře např:: Teachers matter: Attracting, developing and retaining effective teachers (OECD, 2005) a Developing coherent and system-wide induction programmes for beginning teachers: A handbook for policymakers (EU Commission, 2010).
} 
pedagogických pracovníků, jeho současné znění ale nezohledňuje pozici začínajícího učitele ani nevymezuje pozici uvádějícího učitele. ${ }^{5}$

S ohledem na výše zmíněné lze tvrdit, že podpora uvádění začínajících učitelů do praxe zůstává v českém prostředí stále především intuitivním a individuálním úsilím ředitelů škol (Lazarová, 2010, s. 67). Na tuto situaci reaguje předkládaný text, jehož cílem je popsat, jak bez systémové podpory probíhá uvádění začínajících učitelů na českých školách a jaké potřeby v tomto ohledu pocitujuji jednotliví aktéři uvádění.

\section{Uvádění začínajících učitelů do praxe českých škol perspektivou výzkumů}

Pro český pedagogický výzkum není téma adaptace začínajících učitelů na školní praxi neznámé. V této kapitole upozorníme na hlavní teze a výsledky výzkumů realizovaných v nedávné době s důrazem na jejich „bílá místa“.

České pedagogické výzkumy se zabývají adaptačním obdobím (někdy též nazývaným socializačním obdobím) začínajících učitelů jako takovým (Píšová, 2013; Urbánek, 2005), klimatem školy z pohledu začínajících učitelů (Ježek, 2009), mentoringem začínajících učitelů (Píšová et al., 2011; Lazarová, 2010) a především pregraduálním vzděláváním učitelů, které je spojováno s připraveností na roli začínajících učitelů (Vítečková \& Gadušová, 2014; Juklová, 2013; Dytrtová \& Krhutová, 2009; Šimoník, 2005; Havlík, 2004; Urbánek, 2001; Kalhous \& Horák, 1996; Šimoník, 1995).

Za nejzásadnější výsledky zmíněných výzkumů lze považovat zmapování připravenosti začínajících učitelů na praxi ve školách. $Z$ výzkumů plyne, že se čeští začínající učitelé cítí být z vysokých škol dobře vybaveni v otázce teoretických znalostí ve svých předmětech (Vítečková \& Gadušová, 2014; Švec, 2005; Šimoník, 1994), naopak neumí převést naučené znalosti do učitelské praxe. Nejméně se začínající učitelé považují za připravené v otázce řešení kázeňských problémů, práce s neprospívajícími žáky, udržení pozornosti žáků

\footnotetext{
Proběhly také snahy o zavedení standardu učitele, který zmiňuje Strategie vzdělávací politiky České republiky do roku 2020 (MŠMT, 2014a). Ta počítá se zavedením čtyřstupňového kariérního systému učitelů, který by jasně vymezoval vyučovací dovednosti a profesní růst učitelů. Začínající učitelé by podle tohoto systému měli spadat do prvního stupně (KS1) a měli by úzce spolupracovat $\mathrm{s}$ uvádějícími učiteli $\mathrm{s}$ mentorskými dovednostmi. MŠMT předložilo návrh novely zákona č. 563/2004 Sb., o pedagogických pracovnících a o změně některých zákonů, v platném znění, který však v roce 2017 nebyl přijat.
} 
či práce se vzdělávacími dokumenty (Vítečková \& Gadušová, 2014; Šimoník, 1994). Jinými slovy, začínající učitelé se cítí být více připraveni teoreticky (znalostně) ve svých předmětech spíše než v pedagogických, psychologických či didaktických otázkách (Kalhous \& Horák, 1996). Podle Prokešové (2000) se učitelé obecně cítí nepřipraveni na každodenní chod školy, na intenzivní a dlouhodobý kontakt s dětmi a na komunikaci s rodiči. Juklová (2013) to vysvětluje vysokou mírou konzervatismu až nechutí ke změnám na českých vysokých školách. Př́lišnou teoretičnost př́ípravy na pedagogických fakultách a nedostatečný kontakt studentů se školní praxí kritizují také Wernerová (2013), Havlík (2004, 2002), Podlahová (2004) či Průcha (2009).

Zatím nejkomplexnějším šetřením v českém prostředí je publikace Hanušové a kol. (2017), kteří se věnují problematice profesní socializace začínajících učitelů. Zkoumají české začínající učitele mimo jiné z pohledu, zda chtějí ve školství zůstat (stayers), změnit školu (movers) či ze školství úplně odejít (leavers). Výsledky jejich šetření ukázaly, že pouze $65 \%$ dotazovaných chce zůstat na škole, na které momentálně působí. Vzhledem k tomu, že se začínající učitelé cítí být v mnoha ohledech nepřipraveni na svou učitelskou praxi, je nasnadě se domnívat, že potřebují efektivní podpůrná opatření, která zamezí jejich odchodu ze školství. Za nejzásadnější považují Hanušová a kol. (2017) především přiměřenou pracovní zátěž a podporu od kolegů. Jiným způsobem podpory začínajících učitelů může být nabídka dalšího vzdělávání pedagogických pracovníků. Již výzkum Havlíka (2004) ukázal, že 38 \% začínajících učitelů si chce rozšírit či změnit svou kvalifikaci, většina si ji chce rozšírit o konkrétní znalosti (92\%).

Z hlediska podpory, kterou začínající učitelé v českých školách dostávají, je nejčastější přidělení uvádějícího učitele (Hanušová et al., 2017; Vítečková \& Gadušová, 2014; Kašparová et al., 2015). Od něho začínající učitelé očekávají především profesionální zkušenost a profesionální (ale zároveň přátelský a nápomocný) přístup a vedení (Vítečková \& Gadušová, 2014). Začínající učitelé by také ocenili rady od uvádějících učitelů, a to v oblastech, které sami označovali jako problematické a v těch, na které nebyli nijak připravováni v rámci svého studia (řešení problémů vzniklých mezi žáky, zařazení diskuse do výuky apod.). Naopak od uvádějících učitelů neočekávají, že jim poskytnou výukové materiály ani že ocení využívání inovativních výukových metod a technik (Vítečková \& Gadušová, 2014). 
Spíše výjimečně je výzkumná pozornost věnována potřebám uvádějících učitelů a jejich vnímání adaptačního procesu začínajících učitelů. Výjimku tvoří autorky Vítečková a Gadušová (2014), Lazarová (2010) či Píšová a kol. (2011), které uvádějící učitele do svého výzkumu zařadily. Díky tomu víme, že v procesu uvádění kladou důraz na podporu osobnostního i profesionálního rozvoje začínajících učitelů, dále potom na poskytnutí dobrého vedení (průvodcovství) a na pomoc s plánováním jednotlivých lekcí či na hodnocení žáků (Vítečková \& Gadušová, 2014). V poskytování podpory uvedeného druhu se uvádějící učitelé cítí velmi sebevědomě. Naopak nejméně si věří v roli kritického kolegy, který by měl provádět konstruktivní zpětnou vazbu na práci začínajících učitelů. Výzkum Vítečkové a Gadušové (2014) dále poukázal na to, že uvádějící učitelé se ve více než polovině případů zajímají o povinnosti plynoucí z jejich role (65,7 \% uvedlo, že ano). Většina ovšem uvedla, že neprošla žádným školením či kurzem či jiným typem vzdělávání, který by je připravil na roli uvádějícího učitele. Jejich pomoc začínajícím učitelům tak plyne z vlastních zkušeností a je často nesystematická.

Z výše uvedeného vyplývá, že o procesu uvádění začínajících učitelů v českých školách jsou díky představeným výzkumům dostupné určité informace, přesto jsou doposud spíše kusé. Proces uvádění začínajících učitelů do praxe je totiž v českém prostředí mapován především z pohledu jich samotných a téměř výhradně se soustředí na prostředí základní školy. Mezi autory publikujícími v této oblasti (Kasáčová, 2002; Vašutová, 20016; Švec \& Trna, 1999; Spilková, 1996) však existuje shoda, že ani potřeby začínajících učitelů stále nejsou dostatečně zmapovány (tuto mezeru do jisté míry zaplnil nejnovější výzkum Hanušové et al., 2017). Jelikož proces uvádění začínajících učitelů není v českém prostředí doposud nijak systematicky a systémově ukotven, nesou za něj zodpovědnost ředitelé jednotlivých škol. Ti mohou bud' celý proces delegovat na některého z kolegů (např. zástupce ředitele), nebo se za něj stávají zodpovědní sami. Osoby odpovědné za proces uvádění začínajících učitelů spolu s uvádějícími učiteli lze proto považovat vedle začínajících učitelů za nejdůležitější aktéry celého procesu. Ani přes tento fakt se na ně výzkumy zpravidla nezaměřují (s výjimkou šetření TALIS).

Na tento stav se snažíme reagovat komplexním šetřením, jehož vybrané výsledky prezentované $\mathrm{v}$ následující části textu rozšiřují dosavadní

6 Jedná se o publikaci ze slovenského prostředí, kterou uvádíme kvůli těsné spolupráci a návaznosti na českou situaci. 
znalosti o uvádění začínajících učitelů nad rámec pohledu jich samotných také o pohled uvádějících učitelů a osob odpovědných za proces uvádění. ${ }^{7}$ Současně se šetření zaměřilo na mateřské, základní a střední školy.

\section{Představení metodologie výzkumného šetření}

Předkládaná studie prezentuje dílčí výsledky šetření týkajícího se uvádění začínajících učitelů do praxe. ${ }^{8}$

\subsection{Cíl studie, výzkumné otázky}

Cílem textu je popsat současný stav uvádění začínajících učitelů do praxe MŠ, ZŠ a SŠ a zmapovat potřeby jednotlivých aktérů ve zkoumaném procesu. $\mathrm{Z}$ doposud zmíněného vyplývá, že pro uvádění začínajících učitelů do praxe jsou klíčové především poskytnutí uvádějícího učitele (či mentora) začínajícím učitelům a současně systematičnost a plánovitost uvádění začínajících učitelů. Proto si klademe následující výzkumné otázky:

- V jaké míře dochází na školách k přidělování uvádějících učitelů učitelům začínajícím?

- V jaké míře je na školách využíván adaptační plán?

- V jaké míře považují odpovědné osoby systém uvádění začínajících učitelů na své škole za funkční?

- Jaké jsou potřeby jednotlivých aktérů uvádění začínajících učitelů?

- Jaké jsou úvahy začínajících učitelů o vlastní profesní kariéře?

V souvislosti s výše uvedenými otázkami nás zároveň zajímalo, zda a nakolik v jednotlivých zkoumaných oblastech existují rozdíly na různých druzích škol (MŠ, ZŠ, SŠ), zda existují rozdíly z hlediska velikosti sídla školy ${ }^{9}$ a s ohledem

7 Dále budeme používat zkratky ZU (začínající učitel), UU (uvádějící učitel), OO (osoba odpovědná za proces uvádění).

8 Prezentované výsledky vycházejí z projektu SYPO (Systém podpory profesního rozvoje učitelů a ředitelů, reg. č: CZ.02.3.68/0.0/0.0/17_052/0008363, řešeno v rámci projektu Operační program Výzkum, vývoj a vzdělávání). Projekt zpracovává Národní institut dalšího vzdělávání. V prrípadě zájmu lze více informací o projektu najít na https://www.projektsypo.cz.

9 Velikost sídla školy vychází z počtu obyvatel obce, ve které škola sídlí. Proměnnou tvoří šest kategorií: (1) do 1000 obyvatel, (2) mezi 1000 a 5000 obyvatel, (3) mezi 5000 a 25000 obyvatel, (4) mezi 25000 a 90000 obyvatel, (5) mezi 90000 a 1000000 obyvatel, (6) více než 1000000 obyvatel (tj. Praha). 
na velikost školy také z hlediska celkového počtu učitelů působících na ško$\mathrm{le}^{10}$. Dále nás zajímaly př́ípadné rozdíly mezi školami, jejichž 00 vnímají uvádění ZU jako funkční, a školami, jejichž 00 vnímají uvádění ZU jako nefunkční. V souvislosti se ZU jsme potom zkoumali, zda existují odlišnosti mezi ZU do jednoho roku praxe a ZU s delší praxí.

\subsection{Výzkumný design a technika sběru dat}

Vzhledem k cílům práce a stanoveným výzkumným otázkám byl zvolen kvantitativní přístup studie a jako technika sběru dat dotazník. Dotazník byl vytvořen př́mo pro účely realizovaného šetření, přičemž položky v dotazníku byly vytvořeny s oporou o dostupnou literaturu z českého a slovenského prostředí (Hanušová et al., 2017; Kašparová et al., 2015; Vítečková \& Gadušová, 2014; Švaříček, 2007; Šimoník, 2005). Každá skupina aktérů uvádění (ZU, UU, 00) obdržela v rámci stejného sběru dat specifické znění dotazníku, přičemž některé položky byly použity u všech skupin aktérů, aby bylo možné př́ípadné srovnání pohledů na danou oblast.

Při tvorbě dotazníku byly realizovány tzv. kognitivní rozhovory (Vinopal, 2008; Willis, 2005; Belson, 1981) se zástupci potenciálních respondentů na vybraných školách v Brně a okolí. Po zpětné vazbě od respondentů kognitivních rozhovorů byl dotazník upraven (zjednodušení některých položek a doplnění možností odpovědí vhodných pro všechny typy škol). ${ }^{11}$

\subsection{Výběr vzorku}

Rozhodnutí zaměřit se na tři skupiny respondentů (ZU, UU, 00) se projevilo ve výběru vzorku. Vzhledem k tomu, že nebylo možné jednotlivé skupiny respondentů oslovovat přímo, bylo přistoupeno ke zprostředkovanému oslovení. S žádostí o účast na šetř̌ení byly osloveny všechny školy, které ve školním roce 2017/2018 měly alespoň jednoho začínajícího učitele. Tato žádost

10 Velikost školy z hlediska celkového počtu učitelů na škole tvoří pět kategorií: (1) do 10 učitelů, (2) mezi 10 a 20 učiteli, (3) mezi 20 a 35 učiteli, (4) mezi 35 a 50 učiteli, (5) více než 50 učitelů.

11 Finální verze dotazníku sestávala z úvodní (instruktážní) strany a části se samotnými položkami, které byly zaměřeny na pět oblastí. První oblast tvořily sociodemografické údaje respondentů, druhá oblast byla věnovaná procesům uvádění a také potřebám s uváděním spojeným z pohledu začínajících učitelů, třetí z pohledu uvádějících učitelů, další z pohledu osob odpovědných za uvádění začínajících učitelů do praxe a poslední část mapovala zájem všech respondentů o další vzdělávání v kontextu uvádění začínajících učitelů do praxe. Dotazník tvořily ve většině případů položky, v nichž respondenti vybírali podle instrukcí jednu či více z nabízených možností, vždy měli také možnost doplnit vlastní odpověd'. 
zároveň obsahovala pokyny k rozeslání odkazu na dotazník jednotlivým skupinám respondentů.

Díky údajům z výkonového výkazu o ředitelství škol číslo R 13-0112 o aktuálním počtu ZU na školách bylo možné oslovovat jen ty školy, na kterých se ve školním roce 2017/2018 nacházel alespoň jeden ZU do jednoho roku praxe. Oslovování škol bylo uskutečněno ve dvou kolech, přičemž v každém kole proběhlo několik opětovných oslovení. Opětovné oslovování se řídilo vývojem návratnosti dotazníků. Selektivně byly obesílány ty skupiny škol, které byly nadále nedostatečně zastoupené. Tento proces byl ukončen po dosažení horní hranice doporučeného počtu 50 jednotek (srov. Soukup \& Rabušic, 2007) u všech skupin vzorků v rámci jednotlivých typů škol. ${ }^{13}$ Základní přehled počtu respondentů $v$ jednotlivých skupinách nabízí následující tabulka (viz tabulka 1).

Tabulka 1

Základní přehled absolutních četností respondentů výsledného vzorku dle druhu školy

\begin{tabular}{lllll}
\hline & MŠ & Ž̌ & SŠ & Celkem \\
\hline ZU (z toho do 1 roku praxe $\left.{ }^{14}\right)$ & $130(85)$ & $207(152)$ & $108(72)$ & $445(309)$ \\
\hline UU & 98 & 169 & 101 & 368 \\
\hline OO & 164 & 232 & 121 & 517 \\
\hline Celkem & $392(347)$ & $608(553)$ & $330(294)$ & $1330(1194)$ \\
\hline
\end{tabular}

Celkem bylo alespoň jednou osloveno všech 2786 škol, na kterých se dle výkazu R 13-01 (MŠMT, 2017) nacházel alespoň jeden ZU. Respondenti tvořící všechny tři zmiňované vzorky pak pochází z celkem 726 různých škol ${ }^{15}$

12 Tento výkaz mají ředitelé škol povinnost vyplnit podle $§ 28$ odst. 5 zákona č. 561/2004 Sb.

13 Vzhledem k předpokládaným možným rozdílům mezi 1. a 2. stupněm ZŠ bylo cílem dosáhnout minimální hranice 50 jednotek jednotlivých skupin respondentů na každém stupni.

14 Instrukce pro ředitele škol zněla, aby rozeslali e-mail svým ZU, tedy těm, kteří mají do jednoho roku praxe (stejně tak je ZU definován ve výkazu o ředitelství škol číslo R 13-01). Do dotazníku jsme zařadili ověřovací otázku pro ZU, ve které jsme se ptali, zda mají do jednoho roku praxe. ZU měli vybrat z možností ANO/NE. V řadě případů se stalo, že ZU označovali možnost NE, což mohlo být způsobeno několika okolnostmi: učitel měl již dřívěšsí zkušenosti na jiné škole; je učitelem již déle než jeden rok, ale stále se cítí jako ZU a potřebuje podporu; výkaz ředitelé vyplňovali v zárí, mohlo tedy dojít k tomu, že začínající učitelé, které ředitel v září vykázal, měli v době sběru dat již praxi delší než jeden rok. Do analýzy jsme zařadili i tyto učitele proto, že jsme sledovali, zda právě délka praxe má vliv na některý z posuzovaných jevů.

15 Je nutné zmínit, že výsledné vzorky jednotlivých cílových skupin (ZU, UU, OO) je potřeba 
(tj. 26,1 \% z celkového počtu škol s alespoň jedním ZU). Na českých školách se dle výkazu ve školním roce 2017/2018 nacházelo celkem 4773 ZU a 3993 UU. Informace o počtu 00 v populaci není k dispozici. ${ }^{16}$

\subsection{Charakteristika výzkumného vzorku}

Z celkového počtu ZU jich $76 \%$ již dokončilo své vzdělání, zatímco zbývající čtvrtina při práci ještě studuje. U začínajících učitelů s více jak jedním rokem praxe má dokončené vzdělání větší poměr učitelů, ale rozdíl není statisticky významný. Stejně tak zde nejsou významné rozdíly v typu či velikosti školy. Zároveň 72 \% ZU uvádí, že učí zcela dle své aprobace. ${ }^{17}$ Alespoň částečně učí dle své aprobace 19,4\% ZU. Na různých druzích škol však panují výrazné rozdíly. Zatímco v případě MŠ a SŠ uvedlo 80,6 \% ZU, že učí zcela dle své aprobace, na ZŠ je to jen 62,3 \%. Zároveň ale učitelé v MŠ nejčastěji (15,3 \%) reportují, že neučí vůbec dle své aprobace (v případě ZŠ je to 7,2 \%, SŠ 3,7 \%).

Celkově 44,9 \% ZU uvedlo, že jsou zároveň třídními učiteli. ${ }^{18}$ Významně častěji jsou přitom touto funkcí pověřováni začínající učitelé s více jak jedním rokem praxe $(52,7 \%)$ než ZU do jednoho roku praxe $(41,4 \%), \chi^{2}(1, N=438)=4,3$; $p=0,038$. Významné rozdíly samozřejmě existují i na různých druzích škol, přičemž třídnictví je u ZU výrazně méně časté na SŠ (21,3 \%), a naopak častější na ZŠ $(54,4$ \%). Významnou roli sehrává i velikost školy a jejího sídla. ZU působí v roli třídních významně častěji na menších a středně velkých školách (školy do 35 učitelů - 51,9\%, školy nad 35 učitelů - 34,1\%) a na vesnických

považovat za vzájemně nezávislé (tzn. že za každou školu nejsou k dispozici odpovědi od všech skupin respondentů, nýbrž za některou může být např. k dispozici odpověd' pouze od 00, za jinou od 00 i ZU apod.).

16 Ačkoli by se mohlo očekávat, že za uvádění je automaticky odpovědný ředitel školy, realita českých škol je v tomto ohledu poněkud složitější. Odpovědností za uvádění totiž může být pověřena nejen jiná osoba, nýbrž tato odpovědnost může být v rámci školy delegována i na více osob (např jedna odpovědná osoba pro 1. stupeň ZŠ a další pro 2. stupeň ZŠ apod.).

17 Podle aktuálně platné školské legislativy (novela zákona 563/2004 Sb.) se upustilo od termínu aprobace a přešlo se k používání sousloví vzdělávací obory. Nicméně ve školském terénu je pojem aprobace stále rozšířen a učitelům je dobře srozumitelný. Proto jsme se, i po zkušenosti z kognitivních rozhovorů, rozhodli pro jeho použití v dotazníku, a tedy i v tomto textu. Kognitivní rozhovory s učitelkami MŠ potvrdily, že o aprobovanosti lze hovořit také $v$ rámci skupiny učitelek MŠ, i když jsme si vědomi toho, že v tomto případě je přesnější hovořit o jejich kvalifikovanosti.

$18 \mathrm{~V}$ př́ípadě mateřských škol byla tato otázka diskutována v rámci kognitivních rozhovorů, ze kterých vyplynulo, že také v případě MŠ lze hovořit o třídní učitelce, přičemž jí je rozuměna učitelka hlavní, která v rámci třídy zodpovídá za veškerou administrativu. 
školách a školách v menších městech (školy se sídlem do 25 tisíc obyvatel 51,2 \%, školy se sídlem nad 25 tisíc obyvatel - 36,8 \%).

Zajímavý je údaj týkající se uvádějících učitelů - pouze 13,3 \% z nich se vyjádřilo pozitivně k otázce o absolvování nějakého dalšího vzdělávání pro podporu uvádění začínajících učitelů do praxe. Častěji šlo o UU působící na ZŠ $(17,5 \%)$ spíše než na MŠ $(8,3 \%)$ či SŠ $(6 \%)$.

Co se týče funkce, kterou na škole zastávají 00, v 73,5 \% př́padů jde o ředitele či ředitelku školy, v $25 \%$ pak o zástupce ředitele. Velmi významné rozdíly jsou však mezi jednotlivými druhy škol, $\chi^{2}(4, N=510)=66,42 ; p<0,000$. Zatímco v MŠ je odpovědnou osobou ředitel v 82,8\% případů (zástupce v 9,8 \%), na SŠ je tomu jen v 51,7 \% případů (zástupce v 46,7 \%). Na ZŠ je pak odpovědnou osobou v 77,5\% prrípadů ředitel (zástupce ve $22 \%$ ). Podobně významné rozdíly panují v souvislosti s velikostí školy, kde je zřejmý vztah: čím větší škola (z hlediska celkového počtu učitelů), tím více dochází $\mathrm{k}$ přesunu zodpovědnosti za uvádění z ředitele na jeho zástupce, $\chi^{2}$ $(8, N=510)=69,26 ; p<0,000$. Zatímco ve školách do 10 učitelů je v 91,2 \% př́padů odpovědnou osobou ředitel školy, ve školách nad 50 učitelů je odpovědnou osobou ředitel školy pouze ve $46,6 \%$ př́padů, kdežto ve $47,9 \%$ případů je odpovědnou osobou zástupce ředitele.

\section{Vybrané výsledky výzkumného šetření}

Vzhledem k rozsáhlému pojetí realizovaného šetření (celorepublikové, zaměřené na ZU, UU, 00 v mateřských, základních a středních školách) vybíráme při prezentaci jeho výsledků ty, které považujeme za stěžejní s ohledem na cíl textu a položené výzkumné otázky. ${ }^{19}$

\subsection{Přidělování uvádějících učitelů}

V souvislosti s uváděním začínajících učitelů jako takovým byla zaměřena hlavní pozornost na to, nakolik v českých školách dochází k přidělování uvádějících učitelů a zda je využíván tzv. adaptační plán. Co se týče přidělování UU, 86,7 \% odpovědných osob uvádí, že tuto podporu ZU na své škole poskytují. Rozdíly v přidělování uvádějícího učitele mezi různými druhy škol (MŠ, ZŠ, SŠ) jsou jen minimální a nejsou statisticky významné. Poněkud jinou se

19 Veškerá data jsou otevřeně k dispozici na webu projektu SYPO: http://www.projektsypo.cz/ aktuality/ke-stazeni.html. 
však situace jeví z pohledu ZU, kterým byla položena obdobná otázka, totiž zda jim byl oficiálně přidělen uvádějící učitel. Zde pouze 79,6 \% ZU reportuje přidělení UU. Navíc zde existují statisticky významné rozdíly dle druhu školy, $\chi^{2}(2, N=444)=13,62 ; p=0,001$. Zatímco na ZŠ probíhá přidělování UU dle ZU v 86,5 \% př́ípadů, na SŠ je to 77,6 \% a v MŠ dokonce jen $70 \%$. K přidělování UU pak dochází výrazně méně na malých či vesnických školách (školy do 10 učitelů - 71,7 \%; školy se sídlem do 1000 obyvatel - 55,6 \%).

\subsection{Existence adaptačního plánu}

Dalším častým způsobem podpory v období uvádění začínajících učitelů se ukázal být takzvaný adaptační plán. Otázka na jeho existenci a využívání byla položena všem skupinám respondentů, tudíž i v této otázce je možné využít různého pohledu jednotlivých aktérů uvádění. Celkem 33,5 \% 00 uvedlo, že na jejich škole je pro ZU k dispozici plán uvádění, resp. adaptační plán. Existují zde přitom významné rozdíly především mezi MŠ $(48,4$ \%) a zbývajícími druhy škol (na ZŠ $26 \%$; na SŠ 27,6 \%).

V př́ípadě ZU a UU pak byla otázka na existenci adaptačního plánu položena podrobnějším způsobem. Oproti otázce u 00 zde navíc rozlišovala, jestli má škola vypracován plán uvádění a ten je jednoduše následován, nebo je plán uvádění upravován, či dokonce vytvářen ad hoc pro účely uvádění konkrétního začínajícího učitele. Zároveň nás zajímalo, zda je př́ípadně do úprav či tvorby adaptačního plánu zahrnut sám začínající učitel.

Jak naznačuje tabulka níže (tabulka 2), pohled ZU a UU se v souvislosti s existencí a využíváním adaptačního plánu na školách výrazně liší. I z pohledu ZU a UU existují výraznější rozdíly v existenci adaptačního plánu především mezi MŠ a ostatními druhy škol. Zároveň na ZŠ a SŠ existují značné rozdíly v pohledu ZU a UU na to, zda je uvádění řízeno nějakým (adaptačním) plánem. Zatímco dle UU není adaptační plán stanoven ve 41 \% (ZŠ), resp. 36,5 \% případů (SŠ), dle ZU je to až v 63,8 \% (ZŠ), resp. v 63,4 \% případů (SŠ). UU také častěji uváděli, že pokud škola nemá vypracovaný plán uvádění, tak byl nějaký vytvořen ad hoc, at' už s participací začínajícího učitele, nebo i bez ní. Nutno však zároveň připomenout, že co se týče jednotlivých aktérů, jde o separátní vzorky, které neumožňují přímé srovnání. 
Tabulka 2

Existence adaptačního plánu z pohledu začínajících a uvádějících učitelu

\begin{tabular}{ccccccc}
\hline \multicolumn{7}{c}{$\begin{array}{l}\text { Je na Vaší škole stanoven adaptační plán / plán uvádění začínajícího učitele } \\
\text { do praxe? (\%) }\end{array}$} \\
$\begin{array}{c}\text { Ano, je } \\
\text { následován }\end{array}$ & $\begin{array}{c}\text { Ano, byl } \\
\text { prodiskutován }\end{array}$ & $\begin{array}{c}\text { Ne, vytvořen } \\
\text { ad hoc bez ZU }\end{array}$ & $\begin{array}{c}\text { Ne, vytvořen } \\
\text { ad hoc se ZU }\end{array}$ & Ne & Jiné \\
\hline dle ZU & 39,5 & 23,3 & 3,5 & 3,5 & 29,1 & 1,2 \\
\hline MŠ & 16,1 & 8 & 1,7 & 6,3 & 63,8 & 4 \\
\hline ZS & 17,1 & 9,8 & 1,2 & 3,7 & 63,4 & 4,9 \\
\hline SŠ & Ano, je & $\begin{array}{c}\text { Ano, byl } \\
\text { prodiskutován }\end{array}$ & $\begin{array}{c}\text { Ne, vytvořen } \\
\text { ad hoc bez ZU }\end{array}$ & $\begin{array}{c}\text { Ne, vytvořen } \\
\text { ad hoc se ZU }\end{array}$ & Ne & Jiné \\
\hline dle UU & náledován & 19,6 & 5,2 & 10,3 & 29,9 & 6,2 \\
\hline MŠ & 28,9 & 15,7 & 7,2 & 9,6 & 41 & 10,2 \\
\hline ZS & 16,3 & 6,2 & 10,4 & 15,6 & 36,5 & 10,4 \\
\hline ŠS & 20,8 & & & &
\end{tabular}

\section{3 (Ne)funkčnost systému uvádění začínajících učitelů}

OO byly dále dotazovány, zda by ve své škole označily uvádění ZU do praxe jako funkční (ostatním skupinám respondentů tato otázka položena nebyla). Celkem 45,4 \% 00 považuje uvádění na své škole za funkční, existují zde ale významné rozdíly dle jednotlivých druhů škol, $\chi^{2}(2, N=507)=6,26$; $p=0,044$. Zatímco na SŠ 52,9\% 00 považuje uvádění na své škole za funkční, na MŠ je to pouze 38,1 \% 00. V případě ZŠ pak jde o 46,5 \%. Obdobně je patrná významná souvislost s velikostí sídla školy, $\chi^{2}(5, N=507)=23,89$; $\mathrm{p}<0,000$, a s velikostí školy z hlediska celkového počtu učitelů působících na škole, $\chi^{2}(4, N=507)=32,96 ; p<0,000$. Např́íklad na školách do deseti učitelů jen ve $29,8 \%$ př́ípadů považují 00 uvádění za funkční, kdežto u škol nad 50 učitelů je to $65,3 \%$.

Z tabulky níže (tabulka 3) je patrná i významná souvislost mezi tím, zda je uvádění na škole považováno za funkční, a tím, zda na škole dochází k přidělování UU a zda je při uvádění využíván adaptační plán. Na všech druzích škol platí, že školy využívající adaptační plán či přidělování uvádějícího učitele jsou ve významně větší míře zároveň těmi, na nichž je uvádění ZU vnímáno jako funkční. 
Tabulka 3

Souvislost mezi přidělováním uvádějícího učitele, využíváním adaptačního plánu (z pohledu 00) a vnímáním funkčnosti systému uvádění odpovědnou osobou

\begin{tabular}{|c|c|c|c|c|c|c|}
\hline & \multicolumn{3}{|c|}{$\begin{array}{l}\text { Přidělování uvádějícího } \\
\text { učitele }\end{array}$} & \multicolumn{3}{|c|}{ Existence adaptačního plánu } \\
\hline & ano & ne & $\chi^{2} / p$ & ano & ne & $\chi^{2} / p$ \\
\hline MŠ - funkční systém uvádění & $96,7 \%$ & $3,3 \%$ & \multirow{2}{*}{$\begin{array}{l}9,19 \\
0,001\end{array}$} & $70 \%$ & $30 \%$ & \multirow{2}{*}{$\begin{array}{l}17,2 \\
0,000\end{array}$} \\
\hline MŠ - nefunkční systém uvádění & $77,8 \%$ & $22,2 \%$ & & $34,7 \%$ & $65,3 \%$ & \\
\hline ZŠ - funkční systém uvádění & $93,4 \%$ & $6,6 \%$ & \multirow{2}{*}{$\begin{array}{l}4,31 \\
0,038\end{array}$} & $39,8 \%$ & $60,2 \%$ & \multirow{2}{*}{$\begin{array}{l}20,55 \\
0,000\end{array}$} \\
\hline ZŠ - nefunkční systém uvádění & $83,6 \%$ & $16,4 \%$ & & $12,5 \%$ & $87,5 \%$ & \\
\hline SŠ - funkční systém uvádění & $95,2 \%$ & $4,8 \%$ & \multirow{2}{*}{$\begin{array}{l}6,04 \\
0,011\end{array}$} & $38,7 \%$ & $61,3 \%$ & \multirow{2}{*}{$\begin{array}{l}6,8 \\
0,009\end{array}$} \\
\hline SŠ - nefunkční systém uvádění & $78,6 \%$ & $21,4 \%$ & & $15,1 \%$ & $84,9 \%$ & \\
\hline
\end{tabular}

\subsection{Potreby jednotlivých aktérů při uvádění začínajících učitelů do praxe}

\section{Potreby začínajících učitelů}

V souvislosti s potřebami ZU byly položky šetření zaměřeny na několik aspektů. Jednak se zajímaly o to, v jakých oblastech ZU reálně potřebovali podporu či pomoc v posledních třech měsících a jaká je frekvence podpůrných aktivit, které ZU absolvují se svým UU ${ }^{20}$, a spokojenost ZU s touto frekvencí. ZU s touto frekvencí. V neposlední řadě pak bylo zjištováno, jaké př́ípadné další formy podpory (tj. mimo ty, kterých se jim na škole momentálně dostává) by ZU dále uvítali. Vzhledem k omezenému prostoru jsou níže uvedeny v souvislosti se ZU pouze vybraná zjištění.

Nejvíce ZU potřebovali v posledních (třech) měsících pomoc či podporu v oblasti kázeňských problémů (50,1 \%), vedení školní dokumentace $(49,2 \%)$, práce se žáky se speciálními vzdělávacími potřebami $(35,7 \%)$, hodnocení žáků $(35,5 \%)$ a komunikace s rodiči (31,5 \%). Jedinou oblastí, kde se ukázal být významný rozdíl mezi ZU s praxí do jednoho roku a ZU s delší praxí, byla oblast hodnocení žáků, $\chi^{2}(1, \mathrm{~N}=443)=4,94 ; \mathrm{p}<0,026$. Zde více zkušení

20 Dotazník nabízel respondentům $\mathrm{z}$ výběru možností, dále měli $\mathrm{k}$ dispozici volnou kolonku na doplnění vlastní potřeby, kterou nenalezli v nabídce připravené na základě studované literatury k relevantnímu tématu (Hanušová et al., 2017; Vítečková \& Gadušová, 2014). 
ZU potřebovali pomoc či podporu výrazně méně $(27,6 \%)$ než ZU do jednoho roku praxe $(39,2 \%)$.

Nejvíce času tráví ZU se svými UU, proto jsme se jich ptali, jaké aktivity (a jak často) se svými UU provozují. Mezi nejčastěji realizovanými aktivitami (tj. realizovanými alespoň jednou za týden), které ZU dělají se svým UU, figuruje probírání témat vztahujících se k výuce (50\%) a ke školní administrativě (45,5 \%). S o něco menší frekvencí (tj. alespoň jednou za měsíc) pak následuje hodnocení práce začínajícího učitele $(47,6 \%)$ a zpětná vazba k př́ípravě na hodiny (44,9\%). ZU jsou s frekvencí aktivit, které realizují se svými UU, převážně spokojeni. Přesto by 34 \% z nich chtělo více náslechů v hodinách svého UU a 25,5 \% ZU by ocenilo více párové výuky. Frekvence realizovaných aktivit se významně neliší u ZU do jednoho a nad jeden rok praxe, naopak u spokojenosti s frekvencí jednotlivých aktivit se vyskytují významné rozdíly, což reflektuje fakt, že zkušenější ZU (tj. nad jeden rok praxe) již nepotřebují $\mathrm{v}$ takové míre např. zmiňované probírání témat vztahujících se $\mathrm{k}$ výuce či administrativě ani hospitace či náslechy. Co se pak týče dalších forem podpory (mimo aktivity s UU), nejčastěji ZU uváděli, že by uvítali především možnost náslechů v hodinách zkušenějších kolegů (39,8 \%) a možnost sdílení zkušeností s kolegy $(36,4 \%)$.

\section{Potreby uvádějících učitelů}

Celkem 21,3 \% UU uvedlo, že by potřebovalo podporu či pomoc při uvádění ZU do praxe. Přitom významně častěji pocitují potřebu podpory UU na MŠ $(31,6 \%)$, a naopak méně často na ZŠ $(18,9 \%)$ a SŠ $(15,5 \%), \chi^{2}(2, N=356)$ $=8,51 ; \mathrm{p}<0,014$. Velikost sídla školy nehraje významnou roli, určité rozdíly však existují s ohledem na velikost škol, $\chi^{2}(4, \mathrm{~N}=356)=11,71 ; \mathrm{p}<0,020$. Zatímco na nejmenších školách pocit’ují UU potřebu podpory častěji $(32,5 \%$ ), na spíše větších školách (mezi 35 a 50 učiteli) by jen $8 \%$ UU ocenilo nějakou podporu či pomoc během uvádění.

Co se týče konkrétních oblastí, ve kterých by UU potřebovali podporu, mezi nejčastěji uváděné patří problematika vedení hospitací $(29,6 \%)$ a vedení rozhovoru po hospitaci (28 \%). Dále pak UU zmiňují potřebu podpory v oblasti identifikace potřeb ZU (28,5 \%), plánování jeho dalšího rozvoje (28\%) a v oblasti hodnocení práce začínajícího učitele $(26,4 \%)$. Poměrně často pak UU zmiňovali také potřebu podpory v oblasti vedení párové výuky, resp. výuky v tandemu $(26,6 \%)$. 


\section{Potřeby osob odpovědných za proces uvádění}

U osob odpovědných za proces uvádění byla zjištována potřeba podpory v pěti základních oblastech: (1) komunikace, (2) identifikace potřeb, (3) plánování dalšího rozvoje, (4) hodnocení práce a (5) podávání konstruktivní zpětné vazby. Všech pět oblastí podpory přitom bylo vztahováno jak k ZU, tak i k UU. V případě ZU cítí 00 nejvyšší potřebu podpory v oblasti plánování dalšího rozvoje $(57,3 \%)$, podávání konstruktivní zpětné vazby $(53,8 \%)$ a identifikace potřeb $(52,6 \%)$. Ve vztahu k UU dominuje podávání konstruktivní zpětné vazby $(32,5 \%)$ a hodnocení práce uvádějícího učitele $(27,1 \%)$.

Graf níže (obrázek 1) pak zobrazuje, jak se liší vnímaná potřeba podpory 00 v jednotlivých oblastech s ohledem na to, zda 00 vnímají systém uvádění na vlastní škole jako funkční. Jak je z grafu patrné, ve všech oblastech je 00 vnímána vyšší potřeba podpory na těch školách, které dle 00 nemají funkční systém uvádění začínajících učitelů do praxe. Zároveň lze z grafu jasně vidět, že ve všech pěti oblastech vnímají 00 silnější potřebu ve vztahu k ZU spíše než k UU.

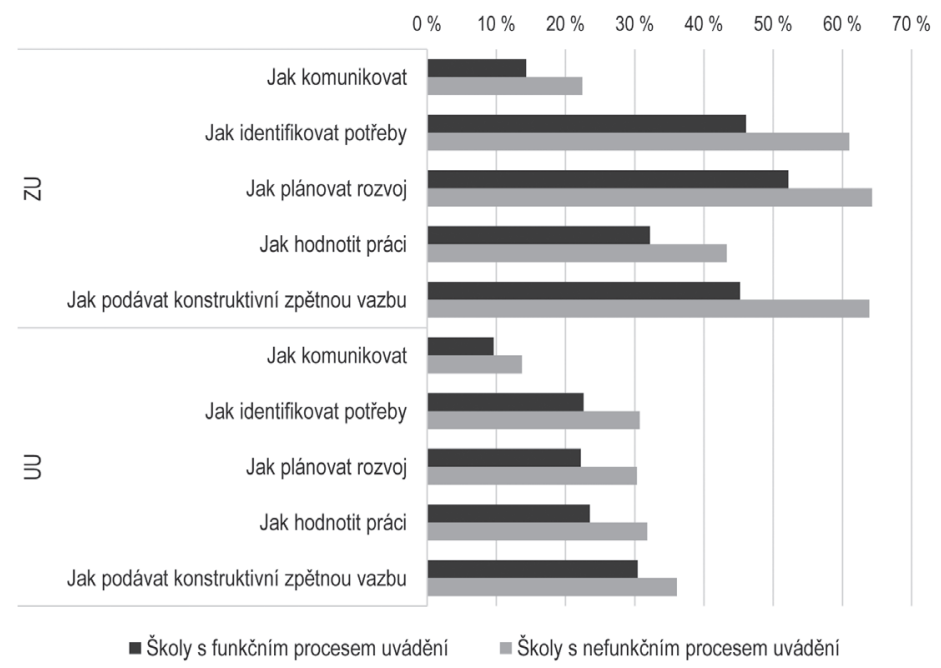

Obrázek 1. Oblasti, ve kterých by osoby odpovědné za proces uvádění uvítaly podporu ve vztahu k vnímání funkčnosti systému uvádění odpovědnou osobou. 
Vzhledem k povaze prezentovaných potřeb se nabízí myšlenka, že tyto potřeby lze jednotlivým skupinám respondentů naplnit v rámci nabídky dalšího vzdělávání či jiné formy podpory. Pouze $8 \%$ dotazovaných ZU, 12,3 \% UU a 3,5 \% 00 totiž uvedlo, že nepotřebují v oblasti uvádění ZU žádnou podporu. Je tedy možné se domnívat, že učitelé nehledě na svou roli při uvádění potřebují rozšířit a posílit patřičné znalosti či dovednosti v analyzované oblasti. Nejvíce pocitují potřebu dalšího vzdělání/podpory dotazované 00 , což je možné vysvětlit do jisté míry tím, že mají ze všech aktérů za celý proces nejvíce zodpovědnosti, které si jsou vědomi.

\section{5 Úvahy o profesní kariéře začínajících učitelů}

V úvodní části textu jsme zmínili, že o období začínajícího učitele se často hovoří jako o období kritickém a začínající učitelé jsou skupinou náchylnější $\mathrm{k}$ drop-outu. Proto jsme se i našich respondentů ptali na jejich úvahy o profesní kariéře v nejbližších letech (tzv. profesní perspektiva).

Podobně jako u Hanušové a kol. (2017) byly v šetření rozlišovány tři základní kategorie: stayers, movers a leavers. Dotazovaní ZU plánují zůstat (stayers) na současné škole v 81,7 \% případů, ve 12,7 \% případů uvažují o změně školy (movers). Zbývající respondenti (5,7 \%) pak spadají do kategorie leavers, přičemž převažují ti, kteří zatím aktivně nehledají jinou práci, ale spíše čekají na lepší nabídku (4,1\%). Analyzovaná data nevykazují významné rozdíly $\mathrm{v}$ profesní perspektivě mezi ZU do jednoho roku praxe a těmi s delší praxí. Zároveň neexistují významné rozdíly mezi různými druhy škol (MŠ, ZŠ, SŠ). Přestože souvislost mezi profesní perspektivou ZU a velikostí školy (resp. velikostí sídla školy) neukazuje jednoznačný trend, zdá se, že kategorie stayers je početnější ve školách do deseti učitelů (85,3 \%), školách v sídlech do tisíce obyvatel $(86,7 \%)$, zároveň v pražských školách $(89,4 \%)$ a školách nad 50 učitelů (87,6 \%). Naopak spíše středně velké školy (tj. 10 až 20 učitelů) a školy ve středně velkých městech (tj. 25000 až 90000 obyvatel) vykazují nižší počty v kategorii stayers (74 \%, resp. 74,1 \%).

Uvažování ZU o profesní kariéře v nejbližších letech také souvisí s tím, zda 00 vnímají systém uvádění na své škole jako funkční, či naopak. Podívámeli se jen na školy, u nichž máme odpovědi jak ZU, tak i od 00, a srovnámeli profesní perspektivu ZU s pohledem 00 na to, zda uvádění ZU do praxe považují na vlastní škole za funkční (viz výše), zjistíme významné rozdíly, $\chi^{2}(2, N=232)=6,81 ; p=0,033$. Zatímco na školách s funkčním systémem uvádění (z pohledu 00) je podíl stayers $88,3 \%$, na školách s nefunkčním 
systémem uvádění je to jen 75,9\%. Rozdíl je pak spíše v tom, že na školách s nefunkčním systémem uvádění ZU více uvažují o změně školy (17 \% oproti 6,7 \% na školách s funkčním systémem uvádění), než že by chtěli zcela opustit oblast školství ${ }^{11}(7,1 \%$ oproti $5 \%$ na školách s funkčním systémem uvádění).

\section{Diskuze a závěr}

Cílem textu bylo popsat současné snahy českých mateřských, základních a středních škol v uvádění začínajících učitelů do praxe a současně zmapovat potřeby jednotlivých aktérů ve zkoumaném procesu. ${ }^{22}$ Poslední odstavce tohoto textu věnujeme diskusi stěžejních výsledků prezentovaných výše.

První výzkumná otázka se zaměřovala na míru přidělování uvádějících učitelů v českých školách. Šetření v tomto případě poskytlo pozitivnější výsledky než doposud realizované výzkumy. Dle šetření Vítečkové \& Gadušové (2014) totiž pouze cca $70 \%$ ZU mělo nějakého uvádějícího učitele, resp. mentora a pouze v přibližně $60 \%$ šlo o oficiální přidělení ředitelem školy. V námi realizovaném šetření však až 87 \% 00 uvádí, že k přidělování UU na jejich škole dochází. Zároveň asi 80 \% ZU uvádí, že jim byl UU oficiálně přidělen. V tomto ohledu naše výsledky doplňují dosavadní poznání a naznačují, že situace v českých školách může být o něco lepší, než se doposud předpokládalo. Rozdíly mezi našimi výsledky a výsledky dřívějšího šetření připisujeme našemu přesněji vymezenému vzorku, který je reprezentativní vzhledem k území, které bylo definováno kraji (vzorek tak byl celoplošný). Současně jsme díky výkazu R13-01 mohli oslovit veškeré školy, které v září 2017 uvedly, že mají alespoň jednoho začínajícího učitele.

Ve druhé výzkumné otázce jsme věnovali pozornost plánu uvádění, resp. adaptačnímu plánu. Zde je třeba zdůraznit především tři hlavní zjištění. Adaptační plán je významně častěji využíván v MŠ než v ZŠ a SŠ, a to

21 Současně nás zajímalo, jak o své budoucí profesní kariéře uvažují UU a O0. Šetření odhalilo zajímavý výsledek, který ukazuje, že tendence k odchodu z aktuální školy či ze školství obecně se netýká výhradně začínajících učitelů. UU i 00 se sice ve více jak v $90 \%$ (UU v 90,1 \%; OO v 91,7 \%) případů cítí být stabilizovaní ve své profesi a na své škole. Velmi specifickou kategorií se však ukázali být UU působící současně na obou stupních ZŠ. Zde totiž pouze $68,2 \%$ z respondentů plánuje zůstat na aktuální škole a 22,7 \% by rádo změnilo školu (naopak nejméně UU uvažujících o změně se nachází na 1. stupni ZŠ: zde celých 97,1 \% plánuje zůstat na aktuální škole).

22 Jak jsme zmínili na začátku textu, v současné době národní systém indukce začínajících učitelů v České republice neexistuje, tudíž smyslem textu nebylo mapovat a hodnotit systém indukce jako takový. 
téměř dvojnásobně často. Zároveň se zdá, že co se týče existence a využívání adaptačního plánu (primárně v ZŠ a SŠ), existují poměrně zásadní rozdíly v pohledu ZU a UU. Konkrétně ZU výrazně častěji uvádějí, že jejich uvádění není řízeno žádným plánem, resp. že o žádném plánu neví. Nabízí se tak otázka, čím jsou tyto rozdíly způsobeny, na kterou by ale bylo nutné odpovědět pomocí doplňujícího výzkumu zaměřujícího se podrobněji na využívání adaptačního plánu a práci s ním.

Třetí výzkumná otázka se týkala vnímané (ne)funkčnosti systému uvádění začínajících učitelů na českých školách pohledem 00. Šetření ukázalo, že existence a využívání adaptačního plánu na všech druzích škol významně souvisí s tím, zda je uvádění na dané škole vnímáno 00 jako funkční (a totéž platí i pro přidělování uvádějícího učitele). Zdá se tedy, že plánování uvádění ZU je jedním ze stěžejních prvků jeho funkčnosti, a to na všech druzích škol.

V rámci čtvrté výzkumné otázky jsme se zaměřovali na potřeby jednotlivých aktérů při uvádění ZU. Rovněž je zde možno, že výsledky provedeného šetření doplnily informace o aktuálních potřebách ZU, které byly již naznačeny v předchozích výzkumech (Hanušová et al., 2017; Píšová \& Hanušová, 2016; Vítečková \& Gadušová, 2014). Shodně s jejich výsledky se i v našem šetření ukázalo, že se ZU cítí být z vysokých škol vybaveni především v otázce teoretických znalostí. ZU proto chtějí více příkladů dobré praxe, o čemž mimo jiné vypovídá naše zjištění, že ZU mají zájem o více hodin náslechů v hodinách svého UU. Pozorování výuky druhého učitele je totiž považováno za zprostředkovanou zkušenost či za zkušenost z druhé ruky (Gavora, 2008) a pro ZU tak náslechy $\mathrm{v}$ hodinách kolegů mohou sloužit jako jistá kompenzace osobních zkušeností, kterých doposud tolik nemají. Zajímavé je také zjištění, že 00 ve více než v polovině př́ípadů označily za svou potřebu v rámci další profesní podpory plánování rozvoje ZU a identifikaci jejich potřeb. Můžeme se tak domnívat, že 00 v řadě prrípadů nevědí, co začínající učitelé potřebují.

Za důležité považujeme také upozornit na výsledky poslední výzkumné otázky týkající se úvah ZU o jejich profesní perspektivě. I zde byly zjištěny poněkud pozitivnější výsledky než v nedávném výzkumu Hanušové a kol. (2017). Zatímco podle jejich šetření pouze cca $70 \%$ ZU (z těch, kteří odpověděli) chce zůstat na současné škole, naše výsledky hovoří spíše o 80 \% (a to na MŠ, ZŠ i SŠ). Za zásadní lze pak považovat také zjištění, že uvažování o profesní perspektivě ZU se významně liší podle toho, zda jde o školu s funkčním systémem uvádění, či nikoli (z pohledu 00). Na školách s funkčním systémem 
uvádění je to až 88 \% ZU, kteří chtějí zůstat na současné škole. To může naznačovat, že pozornost věnovaná na školách začínajícím učitelům (tj. zajištění toho, že je uvádění funkční) se skutečně vyplácí v tom smyslu, že pak významně méně ZU uvažuje o změně školy, či dokonce profese. Výsledky dále naznačily, že zúžení pozornosti výhradně na drop-out začínajících učitelů může být chybou, protože úvahy o změně školy či odchodu ze školství se ukázaly být relevantní i u UU a 00 (i když je možné uvažovat, že důvody zde mohou být jiné než $\mathrm{v}$ případě ZU).

Závěrem lze říct, že text rozšířil dosavadní znalosti o současném stavu uvádění ZU do praxe především o pohled uvádějících učitelů, osob odpovědných za uvádění ZU a také o situaci v mateřských a středních školách. Text je možné považovat za jistou nabídku výsledků z rozsáhlejšího šetření. Kvůli tomu nutně došlo $\mathrm{k}$ některým zjednodušením $\mathrm{v}$ prezentaci výsledků a vzhledem $\mathrm{k}$ omezenému rozsahu časopiseckého příspěvku nebyla věnována větší pozornost hlubší interpretaci nálezů. Vzhledem ke značným specifikům jednotlivých druhů škol (organizace MŠ, ZŠ, SŠ apod.) lze dobře navázat na tento text například (1) dílčím textem zaměřeným na specifika jednotlivých druhů škol a to, jak se projevují v otázce uvádění začínajících učitelů do praxe, nebo (2) textem zaměřujícím se primárně na systémovou podporu a na návrhy na zlepšení v tomto ohledu, který by bylo vhodné opřít o poznatky ze zahraniční praxe.

Přestože záměrem textu nebylo hodnotit a navrhovat systémové zlepšení uvádění začínajících učitelů do praxe českých škol, text má vzhledem k povaze prezentovaných výsledků (mj. kvůli detailnějšímu zmapování potřeb ZU) potenciál $\mathrm{k}$ využití také $\mathrm{v}$ oblasti vzdělávací politiky, a to např́íklad při uvažování o změnách v podpoře uvádění začínajících učitelů do praxe a tvorbě podpůrných opatření pro začínající učitele.

\section{Literatura}

Belson, W. (1981). The design and understanding of survey questions. Aldershot: Gower.

Breaux, A., \& Wong, H. (2003). New teacher induction: How to train, support, and retain new teachers. Mountain View: Harry K. Wong Publications.

Dvořák, D., Starý, K., Urbánek, P., Chvál, M., \& Walterová, E. Česká základní škola: vícepřípadová studie. Praha: Karolinum.

Dytrtová, R., \& Krhutová, M. (2009). Učitel - příprava na profesi. Praha: Grada Publishing.

Eldar, E., Nabel, N., Schechter, C., Talmor, R., \& Mazin, K. (2003). Anatomy of successs and failure: The story of three novice teachers. Educational Research, 45(1), 29-48. 
ETUCE (European Trade Union Comittee for Education). (2008). Teacher Education in Europe. An ETUCE Policy Paper. Dostupné z https://www.csee-etuce.org/images/attachments/ ETUCE_PolicyPaper_en.pdf

EU Commission. (2010). Developing coherent and system-wide induction programmes for beginning teachers: Ahandbook for policymakers. European Commission Staff Working Document SEC. Dostupné z http://ec.europa.eu/assets/eac/education/policy/school/ doc/handbook0410_en.pdf

Gavora, P. (2008). Učitelovo vnímanie svojej profesijnej zdatnosti (self-efficacy). Pedagogika, 58(3), 222-235.

Hanušová, S., Píšová, M., Kohoutek, T., Minaříková, E., Janík, M., Janík, T., ... Ježek, S. (2017). Chtějí zůstat nebo odejít? Začínající učitelé v českých základních školách. Brno: Masarykova univerzita.

Havlík, R. (2002). Mladí učitelé o své přípravě na povolání. In Výzkum školy a učitele. 10. výroční mezinárodní konference ČAPV [CD-ROM]. Praha: PedF UK.

Havlík, R. (2004). Profesionalita učitele jako úkol. In Profese učitele a současná společnost. Sborník referátů z 12. konference ČAPV [CD-ROM]. Ústí nad Labem: Pedagogická fakulta UJEP.

Janík, T., Wildová, R., Uličná, K., Minaříková, E., Janík, M., Jašková, J., \& Šimůnková, B. (2017). Adaptační období pro začínající učitele: zahraniční přístupy a návrhy řešení. Pedagogika, 67(1), 4-26.

Ježek, S. (2009). Začínající učitelé jako informátoři o klimatu školy prizmatem tří metod. Orbis Scholae, 3(1), 45-61.

Johnson, S. M., \& Kardos, S. M. (2005). Bridging the generation gap. Educational Leadership, 62(8), 8-14.

Juklová, K. (2013). Začínající učitel z pohledu profesního vývoje. Hradec Králové: Gaudeamus.

Kalhous, Z., \& Horák, F. (1996). K aktuálním problémům začínajících učitelů. Pedagogika, 46(3), 245-255.

Kasáčová, B. (2002). Učitel’ - profesia a príprava. Banská Bystrica: PF UMB.

Kašparová, V., Holečková, A., Hučín, J., Janík, T., Najvar, P., Píšová, M., ... Ševců, M. (2015). Analytická zpráva z šetření TALIS 2013. Praha: Česká školní inspekce.

Lazarová, B. (2010). Mentoring jako forma kolegiální podpory a strategie dobré školy. Pedagogika, 55(3-4), 254-264.

Loevingerová, J. (1976). Ego development: Conceptions and theories. San Francisco: Jossey-Bass.

MŠMT. (2014a). Strategie vzdělávací politiky České republiky do roku 2020. Dostupné z http://www.msmt.cz/ministerstvo/strategie-vzdelavaci-politiky-2020

MŠMT. (2014b). Kariérní ř́d - Profesní rozvoj pedagogických pracovníků (2014). Dostupné z http://www.msmt.cz/o-webu-msmt/karierni-rad

MŠMT. (2015). Dlouhodobý záměr vzdělávání a rozvoje vzdělávací soustavy České republiky na období 2015-2020. Dostupné z http://www.msmt.cz/vzdelavani/skolstvi-v-cr/ dlouhodoby-zamer-vzdelavani-a-rozvoje-vzdelavaci-soustavy-3

MŠMT. (2017). R 13-01. Výkaz o ředitelství škol podle stavu k 30. 9. 2017. Praha: MŠMT.

OECD. (2005). Teachers matter: Attracting, developing and retaining effective teachers. Paris: OECD.

Píšová, M. (2013). Teacher Professional Socialisation: Objective Dererminants, Orbis Scholae, 7(2), 67-80. 
Píšová, M., Duschinská, K., Kargerová, J., Lampertová, A., Lukavská, E., Szimethová, M., ... \& Kargerová, J. (2011). Mentoring v učitelství. Praha: Karolinum.

Píšová, M., \& Hanušová, S. (2016). Začínající učitelé a drop-out. Pedagogika, 66(4), 386-407.

Podlahová, L. (2004). První kroky učitele. Praha: Triton.

Prokešová, L. (2000). Učitel základní školy a jeho problémy při nástupu do praxe. In J. Kohnová (Ed.), Učitel a jeho univerzitní vzdělávání na přelomu tisíciletí. Sborník referátů z mezinárodní konference (s. 205-209). Praha: PedF UK.

Průcha, J. (2009). Moderní pedagogika. Praha: Portál.

Průcha, J., Walterová, E., \& Mareš, J. (Eds.). (2009). Pedagogická encyklopedie. Praha: Portál.

Rýdl, K. (2014). Vývoj standardizace profese učitele v České republice - nekonečný příběh? Orbis Scholae, 8(3), 9-21).

Sorcinelli, M. D. (1992). New and junior faculty stress: Research and responses. New Directions for Teaching and Learning, 1992(50), 27-37.

Soukup, P., \& Rabušic, L. (2007). Několik poznámek k jedné obsesi českých sociálních věd statistické významnosti. Sociologický časopis/Czech Sociological Review, 43(2), 379-395.

Spilková, V. (1996). Východiska vzdělávání učitelů primárních škol. Pedagogika, 46(2), 135-146.

Stokking, K., Leenders, F., De Jong, J., \& Van Tartwijk, J. (2003). From student to teacher: reducing practice shock and early dropout in the teaching profession. European Journal of Teacher Education, 26(3), 329-350.

Šimoník, O. (1994). Začínající učitel. Brno: Masarykova univerzita.

Šimoník, O. (1995). Začínající učitel: některé pedagogické problémy začínajících učitelů. Brno: Masarykova univerzita.

Šimoník, O. (2005). Příprava budoucích učitelů. Brno: MSD.

Švaříček, R. (2007). Zkoumání konstrukce identity učitele. In R. Švaříček, K. Šedová et al., Kvalitativní výzkum v pedagogických vědách: pravidla hry (s. 335-355). Praha: Portál.

Švec, V. \& Trna, J. (1999). Osvojování klíčových kompetencí učitele. In Zborník Medacta 99. Učitel' pre tretie tisícročie (s. 168-171). Nitra: Slovdidac.

Švec, V. (2005). Ohlédnutí za desetiletým vývojem pedagogické př́ípravy budoucích učitelů. Pedagogická orientace, 15(4), 31-43.

Urbánek, P. (2001). Postoje budoucích učitelů k vlastní profesi. In Nové možnosti vzdělávání a pedagogický výzkum. Sborník z IX. celostátní konference ČAPV s mezinárodní účastí (s. 130-134). Ostrava: PdF OU.

Urbánek, P. (2005). Vybrané problémy učitelské profese: aktuální analýza. Liberec: Technická univerzita v Liberci.

Vašutová, J. (2001). Kvalifikační předpoklady pro nové role učitelů. In E. Walterová (Ed.), Učitelé jako profesní skupina, jejich vzdělávání a podpůrný systém. 1. díl. (s. 19-46). Praha: Univerzita Karlova.

Vinopal, J. (2008). Kognitivní prístupy v metodologii výzkumných šetření: metoda okamžité validizace. Praha: Sociologický ústav AV ČR.

Vítečková, M., \& Gadušová, Z. (2014). Teachers Professional Induction in the Czech Republic and Slovakia. American Journal of Educational Research, 2(12), 1131-1137.

Vyhláška č. 79/1997 Sb. a č. 80/1997, o jednotném systému dalšího vzdělávání učitelů škol poskytujících základní, stř̌ední a vyšší vzdělání a ostatních pedagogických a výchovných pracovníků. 
Wernerová, J. (2013). Hodnocení profesní přípravy studentů učitelství a jejich postoje k profesi. E-pedagogium, 2013(3), 24-37.

Willis, G. B. (2005). Cognitive interviewing: A tool of improving questionnaire design. London: SAGE Publications.

Zákon 563/2004 Sb., o pedagogických pracovnících a o změně některých zákonů, hlava IV.

\title{
Autoři
}

Mgr. Klára Záleská, Ph. D., Masarykova univerzita, Filozofická fakulta, Ústav pedagogických věd, Arne Nováka 1, 60200 Brno, e-mail: zaleska@phil.muni.cz.V rámci projektu SYPO pracuje jako výzkumná pracovnice.

Mgr. Bc. Libor Juhaňák, Masarykova univerzita, Filozofická fakulta, Ústav pedagogických věd, Arne Nováka 1, 60200 Brno, e-mail: juhanak@phil.muni.cz.V rámci projektu SYPO pracuje jako výzkumný pracovník.

Mgr. Kateřina Trnková Ph. D., Národní institut pro další vzdělávání, Kř́ižová 22, 60300 Brno, e-mail: trnkova@nidv.cz.V rámci projektu SYPO pracuje jako týmová manažerka klíčové aktivity Evaluace.

Mgr. Martina Šmahelová, Masarykova univerzita, Fakulta sociálních studií, Institut výzkumu dětí, mládeže a rodiny, Joštova 10, 60200 Brno, e-mail: smahelov@fss.muni.cz.V rámci projektu SYPO pracovala jako výzkumná pracovnice.

\section{Novice teachers and their induction process in kindergartens, primary, secondary schools by the view of its main actors}

\begin{abstract}
Adaptation process for novice teachers is not an isolated process. Colleagues and school management are significantly entering this process. We do not know much about their role and activities in this process. The aim of the present study is therefore to comprehensively map the process of introducing novice teachers to the Czech schools. Design of the study is quantitative survey, in which there were three types of respondents: 1) novice teachers, 2) mentors, 3) persons responsible for the process of introducing new teachers in kindergartens, elementary and secondary schools in the Czech Republic. The results present the perceived professional perspectives of respondents, the characteristics of the current state of the process of introducing new teachers and the basic needs of the monitored groups of respondents in this process.
\end{abstract}

Keywords: novice teacher, mentor, he person responsible for the induction process, novice teachers' support, adaptation plan, further education of teachers 